\title{
Gender in Job Negotiations: A Two-Level Game
}

\section{Citation}

Bowles, Hannah Riley, and Kathleen L. McGinn. 2008. "Gender in Job Negotiations: A Two\#Level Game." Negotiation Journal 24, no. 4: 393-410

\section{Permanent link}

http://nrs.harvard.edu/urn-3:HUL.InstRepos:37986314

\section{Terms of Use}

This article was downloaded from Harvard University's DASH repository, and is made available under the terms and conditions applicable to Other Posted Material, as set forth at http:// nrs.harvard.edu/urn-3:HUL.InstRepos:dash.current.terms-of-use\#LAA

\section{Share Your Story}

The Harvard community has made this article openly available.

Please share how this access benefits you. Submit a story.

Accessibility 


\title{
Gender in Job Negotiations: A Two-Level Game
}

\author{
By Hannah Riley Bowles and Kathleen L. McGinn
}

Hannah Riley Bowles is an Associate Professor at the Harvard Kennedy School. Her e-mail address is hannah_bowles@harvard.edu.

Kathleen L. McGinn is the Cahners-Rabb Professor of Business Administration at Harvard Business School. Her e-mail address is kmcginn@hbs.edu.

\begin{abstract}
We propose taking a two-level-game (Putnam 1988) perspective on gender in job negotiations. At Level One, candidates negotiate with the employers. At Level Two, candidates negotiate with household members. In order to illuminate the interplay between these two levels, we review literature from two separate bodies of literature. Research in psychology and organizational behavior on candidate-employer negotiations sheds light on the effects of gender on Level One negotiations. Research from economics and sociology on intra-household bargaining elucidates how negotiations over the allocation of domestic labor at Level Two influence labor force participation at Level One. In conclusion, we integrate practical implications from these two bodies of literature to propose a set of prescriptive suggestions for candidates to approach job negotiations as a two-level game and to minimize disadvantageous effects of gender on job negotiation outcomes.
\end{abstract}

Key words: gender, compensation, household, labor, negotiation, salary, sex stereotypes, twolevel game

Forthcoming in the Negotiation Journal. Please do not quote or cite without author's permission. 


\section{Gender in Job Negotiations: A Two-Level Game ${ }^{1}$}

The gender wage gap has declined in recent decades, but it has not disappeared. A significant "unexplained” difference in male and female compensation persists, one that cannot be accounted for by controlling for such human capital factors as gender differences in work commitment, education, and experience (O’Neill 2003) or such institutional considerations as unionization (Blau and Kahn 2006). Motivated by this persistent unexplained difference in men’s and women's work compensation, the U.S. Congress has recently introduced a bill called the Paycheck Fairness Act (H.R. 1338 and S.766) that would bolster equal pay and fair labor laws. One action proposed in this legislation is the funding of negotiation training programs for women and girls, presumably because lawmakers believe that gender differences in job negotiation performance are contributing to persistent gender disparities in compensation.

What insights does the literature on gender in negotiation have to offer with regard to how negotiation contributes to or could help diminish gender differences in compensation? ${ }^{2}$ We address this question with reviews of two bodies of literature on gender in negotiation—one from psychology and organizational behavior on candidate-employer negotiations and another from economics and sociology on intra-household bargaining. These literatures have flourished

\footnotetext{
${ }^{1}$ This article is an adapted version of "Untapped Potential in the Study of Negotiation and Gender Inequality in Organizations,” which was written by the authors for the 2008 Academy of Management Annals edited by James Walsh and Arthur Brief.

${ }^{2}$ We use the term "gender differences” to refer to differences between men and women. We use the term "gender" as opposed to "sex" because it connotes socially as opposed to biologically determined patterns of effects (Deaux \& LaFrance, 1998).
} 
independently of one another and offer markedly different perspectives on gender in negotiation. However, we argue that one cannot understand the effects of gender and negotiation on work compensation without recognizing the fundamental interlocks between gender effects in candidate-employer negotiations and gender effects in intra-household bargaining.

\section{Two-Level Job Negotiations: Links between Candidates’ Negotiations at Work and at Home}

In his classic work on the logic of two-level games in diplomacy and domestic politics, Robert Putnam (1988) made the case that diplomatic interactions should be modeled as negotiations interlinked with domestic politics. This metaphor was inspired in part by Richard Walton and Robert McKersie's (1965) behavioral theory of negotiation, which had challenged unitary actor models of labor relations. In abstract form, the metaphor of the two-level game was intended to represent a broad array of situations in which "Negotiators representing two organizations meet to reach an agreement between them [at Level One], subject to the constraint that any tentative agreement must be ratified by their respective organizations [at Level Two]” (Putnam 1988:435).

This two-level game logic of "domestic" ratification of agreements is widely recognized by negotiation scholars and practitioners alike as occurring when the negotiators are representing formal organizations. But negotiation scholars have largely ignored the structural implications of job candidates' domestic relations when studying negotiations with employers. Akin to the diplomat seeking to reach a trade agreement, job candidates have limits on their "zone of possible agreement” (ZOPA) (Lax and Sebenius 1986) with domestic partners and dependents that place constraints on their ZOPA with current or prospective employers. 
The traditional division of the labor between the sexes - in which men are the breadwinners and women the caregivers - creates asymmetries between men and women in terms of how constrained their negotiations with employers (at Level One) are by their negotiations with household members (at Level Two). As discussed in greater detail below, traditional gender ideologies continue to influence the division of domestic labor at Level Two, even when both women and men are competitively employed. Beyond the direct constraints of Level 2 on candidate's Level One negotiations, there is also a broader shadow of traditional domestic relations to be taken into account. As described in the following section, the traditional division of labor between the sexes continues to have an additional indirect influence on job negotiation outcomes through sex stereotypes and pay expectations. ${ }^{3}$ In conclusion, we attempt to integrate these Level-One and Level-Two perspectives and offer prescriptive suggestions for approaching job negotiations as a two-level game.

\section{Level One: Gender Effects on Candidate-Employer Negotiations}

Field research on job negotiations at organizational entry has suggested that male managers and professionals tend to negotiate higher starting pay than their female peers (Gerhart 1990; Brett

\footnotetext{
${ }^{3}$ Traditional gender ideologies also influence the distribution of paid labor between men and women within organizations. The sex segregation of women in lower-paying, femininestereotyped occupations constrains their bargaining power in negotiations over household labor (Reskin 1984; Goldin 1990). For the purposes of this article, we focus on job negotiations at the individual level, which generally do not affect the division of labor at the organizational level.
} (See Bowles and McGinn (2008) for a review of literature on gender in collective bargaining.) 
and Stroh 1997; Dreher and Cox Jr 2000; Bowles and McGinn 2005), with some exceptions in which no gender differences have been found (Seidel, Polzer, and Stewart 2000; O’Shea and Bush 2002). These findings are consistent with reviews of the literature on gender and negotiation more broadly, which report an overall - if somewhat inconsistent - tendency for negotiation outcomes to favor men over women in terms of economic payoffs (Stuhlmacher and Walters 1999; Kray and Thompson 2005).

Some research has suggested that men (as compared to women) receive more in starting pay because they are more likely to negotiate initial offers (Babcock and Laschever 2003; Small, Gelfand, Babcock, and Gettman 2007). (See also article by Greig in this volume on career advancement and the propensity to negotiate.) Other research has found no gender differences in the propensity to negotiate salary (Gerhart and Rynes 1991a; Bohnet and Greig 2007), ${ }^{4}$ and ties women’s lower salary outcomes to gender differences in negotiation performance (Gerhart and Rynes 1991a; Stevens, Bavetta, and Gist 1993; Barron 2003).

\section{Ambiguity Moderates Gender Effects in Negotiation}

One situational factor that moderates gender differences in salary outcomes at organizational entry is the degree of ambiguity for candidates about the negotiating range and appropriate standards of compensation. Hannah Riley Bowles and her colleagues (2005) analyzed job search and outcome data across thirteen industries for 525 graduating MBA students, controlling for a

\footnotetext{
${ }^{4}$ Survey research suggests that, when compared to men, women may be more likely to negotiate such job components as work and travel schedules, which impinge directly on household responsibilities (Bohnet and Greig 2007).
} 
wide array of potential salary predictors on which men and women might differ (e.g., pre-MBA salary, number of job offers, dual-career concerns, etc.).

Based on ratings by career services professionals in three other MBA programs, the researchers divided the industries into low- and high-ambiguity negotiating contexts. Lowambiguity industries were ones in which career services professionals reported that MBA students were well informed about how much to ask for in salary negotiations, whereas high ambiguity industries were ones in which they reported that MBA students were not well informed. There was no significant difference in the variance or mean of salaries in the high-as compared to low-ambiguity industries. Analyzing gender effects on salaries accepted by industry ambiguity, Bowles and colleagues found no significant gender differences in negotiation outcomes in low-ambiguity industries and significant gender differences in salaries accepted in high-ambiguity industries. In those industries in which salary standards were ambiguous, women accepted salaries that were ten percent lower on average than did the men. Bowles and colleagues demonstrated in follow-on experimental studies that when ambiguity with regard to the standards for negotiated agreement declines (e.g., negotiators have no standard vs. a clear standard for agreement), the potential for gender to influence negotiation outcomes decreases. As in the salary study, the experimental results showed that reducing ambiguity with regard to the standards for agreement decreased gender differences in negotiation outcomes, even though the variance in outcomes was a broad in the low- as in the high-ambiguity condition.

In addition to providing insight into gender differences in salary outcomes, the results of the research by Bowles and her colleagues (2005) may also help to explain why gender differences in compensation have been found to be greater in less formalized categories of compensation, such as bonuses (Elvira and Graham 2002) and equity (Lyness and Thompson 
1997) as compared to base salary. Bowles and colleagues have proposed that, in the absence of clear standards for agreement, parties search mental schema, past experience, and the negotiating context for cues for how to enact the negotiation. If negotiators carry gendered associations (e.g., sex stereotypes) to the table or if the context of the negotiation is gendered (e.g., a maledominated organization), then greater ambiguity allows more potential for those gendered associations or the gendered context to influence negotiation performance. In other words, ambiguity itself does not cause gender effects, but it opens the door for the kinds of mental schema and situational factors than can trigger gender effects.

\section{How Gender Shapes Candidates' Negotiations with Employers}

Based on our review of the literature on gender in job negotiations, we have observed two primary mechanisms through which gender influences candidates’ negotiations with employers: sex stereotypes and pay expectations. Both relate back to the traditional division of labor between the sexes. Because men traditionally managed the public realm and women the private in our culture, men have tended to hold higher social and economic status within the broader society than women (Ridgeway and Bourg 2004). Commensurate with their greater social and economic status, men have been expected to be more competent, forceful, and in charge than women (Eagly and Steffen 1984; Eagly 1987; Hoffman and Hurst 1990; Jackman 1994; Conway, Pizzamiglio, and Mount 1996). They have also been mentally associated with higher pay than women (Major and Konar 1984; Rynes, Rosen, and Mahoney 1985; Ostroff and Atwater 2003; Belliveau 2005). These general relationships between gender and status within our society influence the specific circumstances of job negotiations by informing expectations of how male 
and female candidates will and should behave in job negotiations and what types of outcomes (e.g., compensation) they are likely to attain.

\section{Descriptive and Prescriptive Sex Stereotypes}

Descriptive sex stereotypes inform expectations about how men and women will behave or perform in different situations (Burgess and Borgida 1999; Eagly 1987). For instance, men are generally perceived to have an advantage in negotiations over women because they are expected to be more effective at asserting their self-interest and claiming value for themselves, whereas women are expected to act in a more yielding and agreeable and less effective manner in terms of individual performance (Kray, Thompson, and Galinsky 2001). Simple awareness of such descriptive sex stereotypes can influence negotiation performance through a dynamic of fulfilled expectations.

In his research on stereotype threat, Claude Steele showed how subtle awareness of negative stereotypes about the performance abilities of one's group in a domain of personal importance - such as female managers in compensation negotiations - hangs like "a threat in the air” that mentally taxes the individual and undermines performance (for review see Steele 1997). Drawing inspiration from Steele’s research, Laura Kray and her colleagues (2001) showed that exposing negotiators to sex stereotypes favoring male performance in an implicit manner (i.e., below the level of conscious awareness) and telling them that their negotiation performance would be evaluative of their general negotiation ability increased the male advantage in negotiation performance in mixed-sex pairs. 
Prescriptive sex stereotypes, often referred to as “gender roles” (Eagly 1987), influence evaluations of what is attractive or appropriate behavior by men and women (Burgess and Borgida 1999). Prescriptive sex stereotypes make attempting to negotiate for higher compensation a more socially risky endeavor for women than for men, because people not only expect that women will be more agreeable and other-oriented than men, they also believe women should behave in that manner (Wade 2001).

Hannah Riley Bowles, Linda Babcock, and Lei Lai (2007) demonstrated in a series of experiments that evaluators were significantly less inclined to work with a woman who initiated compensation negotiations as compared to one who did not, because they found her overly demanding and lacking in niceness. They showed further that this social risk of negotiating for higher compensation was greater for women than for men, particularly with male evaluators. In a final study, they asked participants to put themselves in the position of the candidate in the same scenario in which previous participants had evaluated candidates. They found that women were significantly less inclined than men to initiate compensation negotiations under those circumstances in which they faced a consistently higher social risk (i.e., with male evaluators). This research shows that it is reasonable for women at times to be more reticent than men to ask for higher pay, because they have to weigh relatively greater social risks against the economic benefits of initiating negotiation.

\section{Pay Expectations}

Another factor that contributes to gender differences in the outcomes of candidate-employer negotiations is differential pay expectations for male and female candidates. Numerous studies show that women tend to have lower pay expectations than men (e.g., Callahan-Levy and Messe 
1979; Crosby 1982; Major and Konar 1984; Major, McFarlin, and Gagnon 1984; Jost 1997;

Rizzo and Zeckhauser 1999). Studies on what researchers call the "entitlement effect" has shown that, in surveys, women tend to report lower career-entry and career-peak salary expectations than men (Major and Konar 1984) and that, in laboratory research, women tend to pay themselves less for equivalent labor than men and to work longer with fewer errors for equivalent pay (Major, McFarlin et al. 1984). Brenda Major and her colleagues argued that this effect reflected gender differences in compensation within the larger society. Because both men and women tend to compare themselves to same-gender others, men derive their compensation standards from a better-paid population than do women (Major and Forcey 1985; McFarlin, Frone, Major, and Konar 1989). When information about appropriate pay standards is less ambiguous and men and women have the same information, the entitlement effect dissipates (Major, McFarlin et al. 1984).

In general, negotiation research has shown that prenegotiation expectations are highly predictive of negotiation outcomes (Zetik and Stuhlmacher 2002). Some researchers have examined specifically how gender differences in salary aspirations relate to job negotiation behavior and performance. Multiple studies replicate the pattern of results observed in entitlement effect research, with women reporting lower pay aspirations than men entering negotiations and, as a result, negotiating less assertively (Major, Vanderslice, and McFarlin 1984; Stevens et al. 1993; Kaman and Hartel 1994; Barron 2003). (See also Eckel, de Oliveira, and Grossman in this volume on gender and the willingness to accept offers in the ultimatum game.)

Both field and experimental research indicates further that those distributing compensation offer more money to men than women, presumably in anticipation that women 
will be willing to settle for less (Belliveau 2005; Solnick 2001; Solnick and Schweitzer 1999). Congruently, Rynes, Rosen and Mahoney (1985) found in a field survey of more than 1,500 managers, compensation administrators, and union officials, that more than 44 percent of those questioned rated women's willingness to work for less money than men to be a "very" or “extremely” important cause of the gender pay gap (Gerhart and Rynes 1991b).

\section{Summary}

Even when we treat Level 1 negotiations between candidates and employers as independent of candidates' domestic relations, the penumbra of the traditional division of labor between the sexes still casts a clear mark. Sex stereotypes motivate gender differences favoring men in job negotiation performance through a combination of fulfilled expectations of male superiority in negotiating ability and gendered social norms with regard to appropriate negotiating behavior. Reflecting and reinforcing men’s higher economic status, differential pay expectations for men and women also influence the outcomes of job negotiations, because they color the negotiation aspirations of both candidates and employers.

\section{Level Two: Gender Effects on Intra-household Bargaining}

Differences between men's and women's outcomes in job negotiations also reflect the gendered allocation of tasks and responsibilities within households. Alternatives, preferences, constraints, and outcomes in “public” negotiations at work are interwoven with alternatives, preferences, constraints, and outcomes in "private” negotiations at home (Hochschild 1997; Bartley, Blanton, and Gilliard 2005). 
In spite of significant increases in women's participation in paid employment, one of the most intractable barriers to gender equality in the workplace remains the inequitable distribution of household labor (Becker 1985). As women have increased the number of hours in paid work outside the home, men have increased the time spent on household labor, but working women still carry a disproportionately heavy load of household tasks relative to working men (Berk and Berk 1983; Hochschild 1990; Blair and Lichter 1991; Bartley et al. 2005). Gender inequality in earnings reflects the fact that greater responsibility at home is significantly related to lesser earnings at work (Becker 1985; Hersch and Stratton 1994). Research in economics and sociology offers complementary explanations for this recursive dynamic.

\section{Bargaining Power}

Economists assert that outcomes in intra-household bargaining reflect earning power outside the home (Manser and Brown 1980; Hersch and Stratton 1994). In the economists’ bargaining power model, the power held by either spouse in negotiations at home is a function of the value one can achieve in negotiations outside the household (Doss 1996). Supporting this view, studies have shown that changes in men's and women's relative earning power on the job market affects the allocation of tasks within the household. Conversely, both men and women reduce their payoffs in the workplace as they take on responsibility within the household, but these negative payoffs disproportionately affect women (Mahoney 1995).

Joni Hersch and Leslie Stratton (1994) also found that women tended to marry men with greater earning power at the time of marriage, and the unequal distribution of household work between spouses often reflects this unequal earning power. When household partners base intrahousehold allocations of tasks and responsibilities on earning power, the partner viewed as 
having lower potential grows increasingly less competitive in the workforce by dedicating time and attention to the home, while the partner viewed as having greater potential grows increasingly more competitive by focusing on education and experience. This creates a selffulfilling cycle in which the partner with less earning power at the beginning of the marriage, usually the woman, realizes an increasing relative disadvantage in the labor force. Research on intra-household bargaining power concludes that even the anticipation - in imagined future or current relationships - that the woman will assume greater household responsibilities than the man contributes to gender differences in human capital investment and, ultimately, to career outcomes (Becker 1985; Hersch and Stratton 1994).

\section{Gender Ideology}

While acknowledging economists' arguments that outside earning potential affects behavior at home, sociologists assert that socially constructed gender ideology is the fundamental driver of behavior and outcomes in intra-household negotiations (Berk and Berk 1983; Parkman 2004). Supporting the gender ideology view, studies have shown how social norms across cultures and time guide the allocation of household tasks (Strober and Chan 1998; Bittman, England, Sayer, Folbre, and Matheson 2003). In both economics and sociology, men and women are seen as actively negotiating household responsibilities, but gender inequities are more malleable in the bargaining power model than they are in the gender ideology model.

Empirical work on gender ideology suggests that the bargaining power model is incomplete because it fails to incorporate the effects of gendered social norms (Kamo 1988; Blair and Lichter 1991; Parkman 2004). As women increase their earnings outside the home, men do take on more responsibilities at home, but women continue to spend a disproportionate amount 
of time on household tasks regardless of their contribution to household income (Bartley et al. 2005). In short, social norms around gender roles trump the effects of wives’ outside earnings (DeMaris and Longmore 1996). For example, research on Israeli couples with children suggests that women's part-time participation in the external labor market actually reinforces, rather than mitigates, traditional allocations of household labor (Stier and Lewin-Epstein 2000). Cross cultural research suggests that these effects are moderated by national culture. Myra Strober and Agnes Chan (1998) studied high-earning dual-career couples in the United States and Japan. More than 40 percent of the U.S. couples in their sample reported roughly equal shares of household tasks for husbands and wives, but this rate was below 15 percent in Japanese households with the same income structure. Other research conducted in the U.S. found that working women's time on household tasks drops not solely as a result of men’s increasing their time on these tasks, but as a result of more money spent on dining out and external sources of household help (Cohen 1998). Strober and Chan concluded that "changes in societal ideology are a prerequisite for changes in behavior, even for highly educated couples, and even when women have some economic bargaining power” (1998: 122).

Women sometimes also maintain traditional household roles in addition to their increased participation in the workplace in order to compensate for deviating from traditional gender roles in employment (Court 1997; Bittman et al. 2003). Men may also act in a similar fashion. Exploring men's relative under-participation in household labor when their earnings drop below their female partner’s earnings, Julie Brines (1994) argued that men “do gender” (West and Zimmerman 1987) at home by maintaining traditionally gendered roles in household tasks as a way of compensating for not maintaining the stereotypical male role in contribution to household income. John Dixon and Margaret Wetherell (2004) have suggested that persistent gender 
inequalities within households reflect a gendered sense of what constitutes fairness in close relationships. Supporting this view, both men and women appear willing to take on household tasks traditionally done by the other, but they are less likely to relinquish tasks that are considered traditional for their gender (Hiller and Philliber 1986). As a result, women may be more willing to add tasks such as home repair than they are to give up tasks such as cooking and childcare (Parkman 2004). Studying Northern Irish farmers' wives working outside the farm to supplement farm income, Roisin Kelly and Sally Shorthall conclude that in order to fully understand intra-household bargaining “cognizance must be taken of historical context, power and gender relations, and bonds of affection” (2002: 341).

\section{Summary}

In sum, part of the recursive dynamic between job negotiations and intra-household bargaining is directly tied to maximizing household earning potential - partners with greater perceived potential earnings (typically men) take on less responsibility at home. But allocations of household labor also reflect traditional gender roles and ideologies within families and societies. Embracing gender ideologies with regard to division of household labor influences job negotiation aspirations: even before a woman has a partner to negotiate with, she might prioritize a flexible work schedule over money in anticipation of being a mother with a husband working out of the home, carrying the load of household labor that traditionally accompanies this household arrangement. Together, bargaining power and gender ideology result in different outcomes for men and women at home, and the resulting allocations of domestic roles and responsibilities affect negotiations for jobs and compensation outside the home. 


\section{Reducing Gender Inequalities in Job Negotiations: Prescriptions in Two-level}

\section{Games}

Recognizing the two-level structure of job negotiations leads to a fuller and more integrative set of considerations than is evident from either level alone. In conclusion, we offer the following suggestions for approaching job negotiations as a two-level game and for minimizing disadvantageous effects of gender on job outcomes. Our suggestions apply most obviously to women in or anticipating long-term heterosexual relationships. However, we believe that the two-level game structure is relevant anyone-man or woman-who is anticipating or involved in a long-term domestic partnership or caregiving relationship that involves collaboration and creates tradeoffs between home or familial responsibilities and work roles. Moreover, even though the literature we have reviewed focuses on compensation as a primary job outcome, we believe the two-level-game structure also applies in contexts in which compensation is generally not negotiable (e.g., government), because it influences a wide array of potential negotiations over valued job attributes (e.g., work assignments, training, and other opportunities for career advancement).

Because the interplay between these two realms is deeply personal and idiosyncratic to the life circumstances of each candidate, our prescriptions, necessarily, point more to paths for critical inquiry than to concrete answers. We also offer more concrete suggestions for approaching Level One than Level Two negotiations because of the intimate nature of decision making at Level Two. We believe, however, that our basic prescriptions for creating value through negotiation apply to both levels. 


\section{Avoid the Fixed-Pie Bias}

In Putnam's original formulation of the two-level game, he conceptualized the bargaining zone at each level as a "win-set” with agreement at one level contingent on an accompanying agreement at the other level: "Thus, agreement is possible only if win-sets overlap, and the larger each winset, the more likely they are to overlap” (1988: 358). As described above, candidates with greater domestic constraints find their potential “win-set” for agreement with employers constrained. It is straightforward, with this logic in mind, to imagine the array of potentially competing tradeoffs candidates may be required to make to achieve agreement across the two levels - ranging from conflicting work and childcare schedules to limitations on the geographic location of work and home.

What requires more imagination and negotiating skill is identifying those points of agreement that “create value” (Lax and Sebenius 1986) across the levels. Negotiators commonly succumb to a "fixed-pie" bias that focuses them on distributive tradeoffs and blinds them from recognizing solutions for making all parties better off (Bazerman and Neale 1983). With regard to gender in job negotiations, traditional work structures, which are premised on the male breadwinner model (Acker 1990; Danieli 2006), and gender ideologies with regard to the division of household labor may further reinforce this natural tendency to see competing problems before cooperative solutions across the two levels. Women, especially, may perceive their roles at work and home as competing (Biernat and Wortman 1991) and have to resist engrained assumptions to negotiate creatively at home and work to enhance the value of their contributions in both realms (Hall 1972). 
One example of a value-creating solution across levels is the negotiation of a flexible work schedule that enables the employee to contribute more hours to the organization and more income to household earnings while still being available at critical hours to the household. Job candidates can realize these types of mutually beneficial solutions if they work actively with household members and employers to identify key interests (e.g., timing preferences and constraints) and innovative options for maximizing value at both levels of negotiation. As Putnam argues in abstract yet provocative terms, “clever players will spot a move on one board that will cause realignments on other boards that will enable them to achieve otherwise unattainable objectives” (1988: 354). The challenge is spotting such moves.

\section{Reduce Ambiguity}

As described above, reducing ambiguity reduces the potential for gender to influence negotiation outcomes. One way to beat gendered pay expectations is to collect the best information available about appropriate compensation standards. Candidates should be wary, however, of the potential for gender bias in the search for information itself. For instance, two factors that collude to lead men and women to different information about appropriate compensation standards are systematic differences in men’s and women's social networks and the tendency to compare oneself to similar others.

Women tend to have more gender-diverse social networks at work than men, but they still tend to be less well-connected to networks of men in their workplace than are men. Because those who control resources within organizations tend to be men, these gender differences in social network configuration put women at a disadvantage in terms of gaining career-related resources and information (Brass 1984, 1985; Ibarra 1992). Women should also be aware of the 
tendency of people in general to compare themselves to similar others (Major and Konar 1984; Shah 1998)., because information on other women's compensation or even on others more generally in female-dominated work areas or occupations is likely to suggest lower compensation standards than more gender-mixed comparisons (Crosby 1982; Major and Forcey 1985; Ostroff and Atwater 2003). Getting the most advantageous comparison information may, therefore, require reaching beyond one's most immediate information sources to gain a broader diversity of perspectives.

Another approach to reducing ambiguity involves thinking carefully about one’s personal preferences for how to manage domestic and organizational role demands and then investigating potential options at home and work for achieving those aspirations. For instance, household members might collectively reexamine taken-for-granted domestic roles (e.g., who does the cooking or bath time or deals with the car), and explore different configurations of household labor that might better serve one’s own and other household members’ personal interests and external role demands. Candidates might also benefit from exploring with employers the organizational meaning and contribution of particularly constraining job attributes. Some of the traditionally unquestioned job features (e.g., “face time”) that create zero-sum conflicts across the two levels are highly ambiguous in terms of their value to organizations and to careers. Greater clarity on what matters most to employers and, career wise, to oneself could illuminate creative alternatives for better serving role demands at both levels - and oneself.

\section{Use Awareness of Gender Bias}

Stereotypes and other gender biases are most insidious when they are harbored below the level of conscious awareness. When bias is made explicit, people can resist it, whereas subtle 
associations influence behavior in less controllable ways (Steele 1997; Kray et al. 2001; Kray, Galinsky, and Thompson 2002). Candidates may benefit from making themselves more explicitly self-aware about how gender influences their home and work environment, so that they can make more conscious choices about how gender influences their preferences and behavior or not. Questioning together with domestic partners and dependents whether a traditionally gendered division of labor is the best solution for the household might suggest some alternative arrangement that make everyone better off.

Candidates can also think strategically about ways to avoid gender bias in the workplace-and this does not necessarily mean avoiding asking for higher pay. For instance, research on gender and social influence shows that women can act competent in a stereotypically masculine away and still avoid social backlash if they act both friendly and competent as opposed to simply competent (Carli, LaFleur, and Loeber 1995). Similarly, new research on gender in negotiation suggests that women can overcome the social risks of initiating compensation negotiations if they frame their request in a way that communicates their concern for maintaining good relationships within the organization (Bowles and Babcock 2008). There are no "one size fits all” solutions for how women should behave. Women should judge for themselves what they think will work best within their particular organizational circumstances, but they are likely to benefit - even more so than men - from consciously weighing the potential social, as well as economic, implications of their strategic choices in light of gender stereotypes.

\section{Find the Right Partners}

Ultimately, the challenge is finding the right partners with whom to negotiate across levels. There is encouraging evidence that employers are coming to recognize candidates' two-level job 
negotiations. For example, Deloitte Touche USA endured years of often-unsuccessful job negotiations with professionals whose lives were incompatible with the traditional work schedule involved in big-firm consulting. Gradually, due to employee and client demands, they came to see the need to accommodate their employees’ two-level negotiations. The result was a fundamental change in the way professionals in the firm manage their careers. The firm identified four dimensions of career progression—role, pace, location and schedule, and workload—and now works with their employees to build careers that are dynamically customized around these four dimensions as the professionals’ preferences change with changes in life outside work. Deloitte considers “Mass career customization,” as they call the program, critical to their adaptability and viability as an organization (Benko and Weisberg 2007).

Scholars studying contemporary career paths also describe how managers and professionals are playing a more influential role in the shaping of their personal career trajectories than was the case in the past when firm loyalty was more prevalent and justified (Arthur, Inkson, and Pringle 1999; Arthur and Rousseau 2001). In her book on “I-Deals,” Denise Rousseau (2005) documents an array of idiosyncratic work arrangements that employers work out with candidates to attract and maintain talent in their organizations. Talented job candidates have reason to be optimistic about finding negotiating partners that will work with them to identify creative solutions to their two-level job negotiation dilemmas.

\section{Conclusion}

The effects of gender on job negotiations are best understood if negotiations at work are viewed as a two-level game in which candidates' job outcomes are the product of negotiations with 
domestic partners and dependents as well as prospective employers. Separate bodies of research on gender in candidate-employer negotiations and on gender in intra-household bargaining offer complementary insights into these two levels of negotiation. Taking stock of the practical implications of this literature may help candidates overcome disadvantageous effects of gender on job negotiations and facilitate the creation of greater value for their employers, their loved ones, and themselves.

\section{References}

Acker, J. 1990. Hierarchies, jobs, bodies: A theory of gendered organizations. Gender and Society 4 (2): 139-158.

Arthur, M. B., Inkson, K., and Pringle, J. K. 1999. The new careers: Individual action and economic change. Thousand Oaks, CA: Sage.

Arthur, M. B., and Rousseau, D. M. (Eds.). 2001. The boundaryless career: A new employment principle for a new organizational era. New York: Oxford University Press.

Babcock, L., and Laschever, S. 2003. Women don’t ask. Princeton, NJ: Princeton University Press.

Barron, L. A. 2003. Ask and you shall receive? Gender differences in negotiators' beliefs about requests for a higher salary. Human Relations 56(6): 635-662.

Bartley, S. J., Blanton, P. W., and Gilliard, J. L. 2005. Husbands and wives in dual-earner marriages: Decision-making, gender role attitudes, division of household labor, and equity. Marriage and Family Review 37(4): 69-74. 
Bazerman, M. H., and Neale, M. A. 1983. Heuristics in negotiation: Limitations to effective dispute resolution. In M. H. Bazerman and R. J. Lewicki (Eds.), Negotiating in organizations (pp. 51-67). Beverly Hills, CA: Sage.

Becker, G. S. 1985. Human capital, effort, and the sexual division of labor. Journal of Labor Economics 3(1): 33-58.

Belliveau, M. A. 2005. Blind ambition? The effects of social networks and institutional sex composition on the job search outcomes of elite coeducational and women's college graduates. Organization Science 16(2): 134-141.

Benko, C., and Weisberg, A. 2007. Mass career customization: Aligning the workplace with today’s nontraditional workforce. Boston: Harvard Business School Press.

Berk, R. A., and Berk, S. F. 1983. Supply-side sociology of the family: The challenge of the new home economics. Annual Review of Sociology 9: 375-395.

Biernat, M., and Wortman, C. B. 1991. Sharing of home responsibilities between professionally employed women and their husbands. Journal of Personality and Social Psychology 60(6): 844-860.

Bittman, M., England, P., Sayer, L., Folbre, N., and Matheson, G. 2003. When does gender trump money? Bargaining and time in household work. American Journal of Sociology 109(1): 186-214.

Blair, S. L., and Lichter, D. T. 1991. Measuring the division of household labor: Gender segregation of housework among American couples. Journal of Family Issues 12(1): 91113. 
Blau, F. D., and Kahn, L. M. 2006. The U.S. gender pay gap in the 1990s: Slowing convergence. Industrial and Labor Relations Review 60(1): 45-66.

Bohnet, I., and Greig, F. 2007. Gender matters in workplace decisions. Negotiation(April): 4-6.

Bowles, H. R., and Babcock, L. 2008. When doesn't it hurt her to ask? Framing and justification reduce the social risks of initiating compensation negotiations (Working Paper): Harvard Kennedy School.

Bowles, H. R., Babcock, L., and Lai, L. 2007. Social incentives for gender differences in the propensity to initiate negotiations: Sometimes it does hurt to ask. Organizational Behavior and Human Decision Processes 103(1): 84-103.

Bowles, H. R., and McGinn, K. L. 2005. Claiming authority: Negotiating challenges for women leaders. In D. M. Messick and R. M. Kramer (Eds.): The psychology of leadership: New perspectives and research (pp. 191-208). Mahwah, NJ: Erlbaum.

Bowles, H. R. and McGinn, K. L. 2008. Untapped potential in the study of negotiation and gender inequality in organizations. In J. P. Walsh \& A. Brief (Eds.), Academy of Management Annals.

Brass, D. J. 1984. Being in the right place: A structural analysis of individual influence in an organization. Administrative Science Quarterly 29(4): 518-539.

Brass, D. J. 1985. Men’s and women's networks: A study of interaction patterns and influence in an organization. Academy of Management Journal 28(2): 327-343.

Brett, J. M., and Stroh, L. K. 1997. Jumping ship: Who benefits from an external labor market career strategy? Journal of Applied Psychology 82(3): 331-341. 
Brines, J. 1994. Economic dependency, gender, and the division of labor at home. The American Journal of Sociology 100( 3): 652-688.

Burgess, D., and Borgida, E. 1999. Who women are, who women should be: Descriptive and prescriptive gender stereotyping in sex discrimination. Psychology Public Policy and Law 5(3): 665-692.

Callahan-Levy, C., and Messe, L. A. 1979. Sex differences in the allocation of pay. Journal of Personality and Social Psychology 37(3): 433-446.

Carli, L. L., LaFleur, S. J., and Loeber, C. C. 1995. Nonverbal behavior, gender, and influence. Journal of Personality and Social Psychology 68(6): 1030-1041.

Cohen, P. N. 1998. Replacing housework in the service economy: Gender, class, and raceethnicity in service spending. Gender and Society 12(2): 219-231.

Conway, M., Pizzamiglio, M. T., and Mount, L. 1996. Status, communality, and agency: Implications for stereotypes of gender and other groups. Journal of Personality and Social Psychology 71(1): 25-38.

Court, M. 1997. Who does what at your place? Women educational leaders' experiences of gender-segregated work. Women in Management Review 12(1): 17.

Crosby, F. 1982. Relative deprivation and working women. New York: Oxford University Press.

Danieli, A. 2006. Gender: The missing link in industrial relations research. Industrial Relations Journal 37(4): 329-343.

Deaux, K., \& LaFrance, M. (1998). Gender. In D. T. Gilbert, S. Fiske \& G. Lindsey (Eds.), The handbook of social psychology (4th ed., pp. 788-827). Boston: McGraw-Hill. 
DeMaris, A., and Longmore, M. A. 1996. Ideology, power, and equity testing competing explanations for the perception of fairness in household labor. Social Forces 74(3): 10431071.

Dixon, J., and Wetherell, M. 2004. On discourse and dirty nappies: Gender, the division of household labour and the social psychology of distributive justice. Theory and Psychology 14(2): 167-189.

Doss, C. R. 1996. Testing among models of intrahousehold resource allocation. World Development 24: 1597-1609.

Dreher, G. F., and Cox Jr. T. H. 2000. Labor market mobility and cash compensation: The moderating effects of race and gender. Academy of Management Journal 43(5): 890-900.

Eagly, A. H. 1987. Sex differences in social behavior: A social-role interpretation. Hillsdale, NJ: Erlbaum.

Eagly, A. H., and Steffen, V. J. 1984. Gender stereotypes stem from the distribution of women and men into social roles. Journal of Personality and Social Psychology 46(4): 735-754.

Eckel, C. C., de Oliveira, A. C. M., and Grossman, P. J. 2008. Gender and negotiation in the small. Negotiation Journal 24(4) INSERT PAGE NUMBERS AT PROOF STAGE:

Elvira, M. M., and Graham, M. E. 2002. Not just a formality: Pay system formalization and sexrelated earnings effects. Organization Science 13(6): 601-617.

Gerhart, B. 1990. Gender differences in current and starting salaries: The role of performance, college major, and job title. Industrial and Labor Relations Review 43(4): 418.

Gerhart, B., and Rynes, S. 1991a. Determinants and consequences of salary negotiations by male and female MBA graduates. Journal of Applied Psychology 762): 256-262. 
Gerhart, B., and Rynes, S. 1991b. Determinants and consequences of salary negotiations by ma le and female MBA graduates. Journal of Applied Psychology 762): 256.

Goldin, C. 1990. Understanding the gender gap: An economic history of American women. New York: Oxford University Press.

Hall, D. T. 1972. A model of coping with role conflict: The role behavior of college educated women. Administrative Science Quarterly 17(4): 471-486.

Hersch, J., and Stratton, L. S. 1994. Housework, wages, and the division of housework time for employed spouses. American Economic Review 84(2): 120.

Hiller, D. V., and Philliber, W. W. 1986. The division of labor in contemporary marriage: Expectations, perceptions, and performance. Social Problems 33(3): 191-201.

Hochschild, A. R. 1990. The second shift: Inside the two-job marriage. New York: Morrow/Avon.

Hochschild, A. R. 1997. The time bind: When work becomes home and home becomes work. New York: Metropolitan Books.

Hoffman, C., and Hurst, N. 1990. Gender stereotypes: Perception or rationalization? Journal of Personality and Social Psychology 58(2): 197-208.

Ibarra, H. 1992. Homophily and differential returns: Sex differences in network structure and access in an advertising firm. Administrative Science Quarterly 37(3): 422-447.

Jackman, M. R. 1994. The velvet glove: Paternalism and conflict in gender class and race relations. Berkeley, CA: University of California Press. 
Jost, J. T. 1997. An experimental replication of the depressed-entitlement effect among women. Psychology of Women Quarterly 21(3): 387-393.

Kaman, V. S., and Hartel, C. E. J. 1994. Gender differences in anticipated pay negotiation strategies and outcomes. Journal of Business and Psychology 92): 183-197.

Kamo, Y. 1988. Determinants of household division of labor resources, power, and ideology. Journal of Family Issues 9(2): 177-200

Kelly, R., and Shortall, S. 2002. 'Farmers’ wives’: Women who are off-farm breadwinners and the implications for on-farm gender relations. Journal of Sociology 38(4): 327-343.

Kray, L. J., Galinsky, A. D., and Thompson, L. 2002. Reversing the gender gap in negotiations: An exploration of stereotype regeneration. Organizational Behavior and Human Decision Processes 87(2): 386.

Kray, L. J., and Thompson, L. 2005. Gender stereotypes and negotiation performance: A review of theory and research. In B. M. Staw and R. Kramer (Eds.): Research in Organizational Behavior Series (Vol. 26, pp. 103-182). Greenwich, CT: JAI Press.

Kray, L. J., Thompson, L., and Galinsky, A. 2001. Battle of the sexes: Gender stereotype confirmation and reactance in negotiations. Journal of Personality and Social Psychology 80(6): 942-958.

Lax, D. A., and Sebenius, J. K. 1986. The manager as negotiator: Bargaining for cooperation and competitive gain. New York: Free Press.

Lyness, K. S., and Thompson, D. E. 1997. Above the glass ceiling? A comparison of matched samples of female and male executives. Journal of Applied Psychology 82(3): 359-375. 
Mahoney, R. 1995. Kidding ourselves: Breadwinning, babies and bargaining power. New York: Basic Books.

Major, B., and Forcey, B. 1985. Social comparisons and pay evaluations: Preferences for samesex and same-job wage comparisons. Journal of Experimental Social Psychology 21(4): 393-405.

Major, B., and Konar, E. 1984. An investigation of sex differences in pay expectations and their possible causes. Academy of Management Journal 274): 777-792.

Major, B., McFarlin, D. B., and Gagnon, D. 1984. Overworked and underpaid: On the nature of gender differences in personal entitlement. Journal of Personality and Social Psychology 476): 1399-1412.

Major, B., Vanderslice, V., and McFarlin, D. B. 1984. Effects of pay expected on pay received: The confirmatory nature of initial expectations. Journal of Applied Social Psychology 14(5): 399-412.

Manser, M., and Brown, M. 1980. Marriage and household decision-making: A bargaining analysis. International Economic Review 21(1): 31-44.

McFarlin, D. B., Frone, M. R., Major, B., and Konar, E. 1989. Predicting career-entry pay expectations: The role of gender-based comparisons. Journal of Business and Psychology 3(3): 331-340.

O’Neill, J. 2003. The gender gap in wages, circa 2000. American Economic Review 932): 309314.

O’Shea, P. G., and Bush, D. F. 2002. Negotiation for starting salary: Antecedents and outcomes among recent college graduates. Journal of Business and Psychology 16(3): 365-382. 
Ostroff, C., and Atwater, L. E. 2003. Does whom you work with matter? Effects of referent group gender and age composition on managers' compensation. Journal of Applied Psychology 88(4): 725-740.

Parkman, A. M. 2004. Bargaining over housework: The frustrating situation of secondary wage earners. American Journal of Economics and Sociology 63(4): 765-794.

Putnam, R. D. 1988. Diplomacy and domestic politics: The logic of two-level games. International Organization 42(3): 427-460.

Reskin, B. F., ed. 1984. Sex segregation in the workplace: Trends explanation and remedies. Washington, D.C.: National Academy Press.

Ridgeway, C. L., and Bourg, C. 2004. Gender as status: An expectation states theory approach. In A. H. Eagly, A. E. Beall and R. J. Sternberg, (Eds.): The psychology of gender pp. 217-241. New York: Guliford Press.

Rizzo, J. A., and Zeckhauser, R. J. 1999. Pushing incomes to reference points: Why do male doctors earn more? Journal of Economic Behavior and Organization 63(3): 514-536.

Rousseau, D. 2005. I-deals idiosyncratic deals employees bargain for themselves. Armonk, NY: M. E. Sharpe.

Rynes, S., Rosen, B., and Mahoney, T. A. 1985. Evaluating comparable worth: Three perspectives. Business Horizons 28(4): 82.

Seidel, M.-D. L., Polzer, J. T., and Stewart, K. J. 2000. Friends in high places: The effects of social networks on discrimination in salary negotiations. Administrative Science Quarterly 45(1): 1-24. 
Shah, P. P. 1998. Who are employees’ social referents? Using a network perspective to determine referent others. Academy of Management Journal 41(3): 249-268.

Small, D. A., Gelfand, M., Babcock, L., and Gettman, H. 2007. Who goes to the bargaining table? The influence of gender and framing on the initiation of negotiation. Journal of Personality and Social Psychology 93(4): 600-613.

Solnick, S. J. 2001. Gender differences in the ultimatum game. Economic Inquiry 39(2): 189200.

Solnick, S. J., and Schweitzer, M. E. 1999. The influence of physical attractiveness and gender on ultimatum game decisions. Organizational Behavior and Human Decision Processes 79(3) 199-215.

Steele, C. M. 1997. A threat in the air: How stereotypes shape intellectual ability and performance. American Psychologist 52(6): 613-629.

Stevens, C. K., Bavetta, A. G., and Gist, M. E. 1993. Gender differences in the acquisition of salary negotiation skills: The role of goals, self-efficacy, and perceived control. Journal of Applied Psychology 78(5): 723-735.

Stier, H., and Lewin-Epstein, N. 2000. Women’s part-time employment and gender inequality in the family. Journal of Family Issues 21(3): 390-410.

Strober, M. H., and Chan, A. M. K. 1998. Husbands, wives, and housework: Graduates of Stanford and Tokyo universities. Feminist Economics 4(3): 97-127.

Stuhlmacher, A. F., and Walters, A. E. 1999. Gender differences in negotiation outcome: A meta-analysis. Personnel Psychology 52(3): 653-677. 
Wade, M. E. 2001. Women and salary negotiation: The costs of self-advocacy. Psychology of Women Quarterly 25(1): 65-76.

Walton, R. E., and McKersie, R. 1965. A behavioral theory of labor negotiations. New York: McGraw Hill.

West, C., and Zimmerman, D. H. 1987. Doing gender. Gender and Society 1(2): 125-151.

Zetik, D. C., and Stuhlmacher, A. F. 2002. Goal setting and negotiation performance: A metaanalysis. Group Processes and Intergroup Relations 5(1): 35-52. 